\title{
The Risk Research of Economical Benefits of Real Estate Listed Companies based on Logistic
}

\author{
Jianlin YUAN \\ LiaoNing University of Technology, LiaoNing, China
}

\begin{abstract}
The article analyzes the factors that influence the risk of economical benefits of real estate listed companies; the risk factors mainly include management risk, financial risk, land risk, sale risk, and policy risk. According to the analysis of risk factors, the article establishes the index system of the risk and builds effective principal risk model of real listed estate companies. Based on this, the article uses Logistic methods to evaluate the risk of the economic benefits of listed real estate companies in 2012, pointing out the risk of economic benefits of listed real estate companies.
\end{abstract}

KEYWORD: Real Estate Listed Companies; Economical Profits; the Risk Evaluation

\section{FACTORS AFFECTING THE REAL ESTATE LISTING CORPORATION ECONOMIC RISK}

The high profit of real estate, it is that it doomed to contain enormous risks. In order to ensure the effectiveness of the real estate industry, we must control its risk, so it can play a leading role in economic development. Real estate risk is the result of the interaction of internal and external factors, is associated with the real estate projects throughout the construction and development process, grasping the various risks of real estate, judging risks of real estate, will ensure the real estate industry the maximum benefit. The main factors affecting the real estate economic benefit are:

\subsection{Management risk of real estate}

Real estate management risk is the potential economic losses are caused by the real estate industry because real estate management measures and decisions-making are not suitable for the actual; real estate management risk often has a hidden, and is difficult to reflect in a short time.

\subsection{Account risk of real estate}

New account standards defines financial risk is the risk that lies in the financial activities of the enterprise, in a certain period of time, due to a variety of the internal and external environment and many factors, it is deviation from the actual financial results and expected financial results, it is the possible loss. To the real estate development enterprises, it mainly refers to loss that the investments of the real estate enterprises are not recovered and the failure of their remuneration.

\subsection{Land risk of real estate}

Land cost of real estate constitute a large part of the cost of real estate, you can say the land has a direct impact on the economies of the real estate, but also it is the biggest risk of the real estate industry economic benefits. View from our land auction system, the government has to get up to 40 percent of the revenue from the land auction, no doubt the government gains added to the real estate income, thus affecting the economic benefits of the real estate industry, increasing its economic risk.

\subsection{Sales risk of real estate}

The real estate business benefits get through their production. If commodities can be identified by consumer, there is a sufficient guarantee of its economic benefits; on the contrary, its economic benefits are certain risks. Real estate commodities market will encounter a number of uncertainties. These uncertainties will affect the distribution of the real estate, if the risk happens; the real estate companies would suffer losses. The dynamic and uncertain of supply and demand of the real estate market is source of risk that determines the revenue of the operators. 


\subsection{Policy risk of real estate}

Real estate policy risk is the potential economic loss because government policies of real estate are changed. China economic is continuous developing; there will be a lot of problems and contradictions. In order to continue to promote the sustainable development of the economy, policies will make adjustments and specifications according to the different circumstances, but the real estate investment cycle is relatively long, it is difficult to adjust in the short term, the flexibility to make changes is lagging behind, affecting the economic benefits of the real estate industry.

\section{THE RISK INDEX OF ECONOMIC BENEFIT OF REAL ESTATE LISTING CORPORATION}

\subsection{The principle of the risk index of economic benefit of real estate listing Corporation}

\subsubsection{The principle of systematic and scientific}

There are many risk factors that affect the economic benefits of listed real estate companies. Systematic is that these index are the connection each other. Scientific index system mainly reflects the combination of theory and practice, it ensures that these indicators can be calculated with the scientific method, and can objectively reflect the actual situation of the real estate development.

\subsubsection{The principle of testability}

Real estate development involves more contents, if we correctly evaluate the development security of real estate, the meaning of index must be clear, the data should be gathered convenient and simple calculated, at the same time, the entire evaluation index system should have comparability; the same indicators should have comparability in history. From the point of history and reality, security evaluation of the real estate development and its economic benefits should be evaluated.

\subsubsection{The principle of dynamic}

The real estate development is a dynamic process, with the industrial policy, the domestic and international situation will be changed, resources, market supply and demand relationship will be changed, so the right adjustments and decisionmaking continue to make. In order to properly reflect the risks that exist in a different situation, different stages of the development process, the index should be adjusted.

\subsubsection{The principles of independence and unity}

Independence is that index system more accurate and comprehensively reflects the evaluation of the object, as much as possible reduces the crossresistance with other indicators, there is no containment relationships between each other. So the entire index system is simple and easy to count. Unity is that index system is coordination; unity is relatively independent of the indicators and becomes independent. Independent and unity relationship does not conflict.

\subsection{The risk index system of economic benefit of real estate listing Corporation}

Fully consider the factors that affect the real estate and economic benefits, according to the real estate economic benefits risk index system, I establish risk evaluation index system of the real estate economic benefits. It is shown in Figure 1.

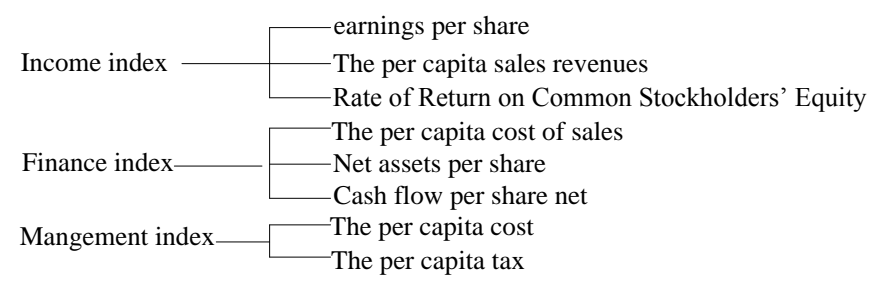

Figure 1 risk evaluation index system of the real estate economic benefits

\section{THE RISK EVALUATING MODEL OF ECONOMIC BENEFIT OF REAL ESTATE LISTED COMPANIES}

\subsection{The principal component of the economic benefits risk model of the real estate listed companies}

\subsubsection{The risk indicators matrix of the real estate economic benefits}

Suppose variables are $\mathrm{m}$ and related each other, its meaning is the original results of the risk of real estate economic benefits, the number of samples is $\mathrm{n}$, then the real estate economic benefits of risk indicators matrix is:

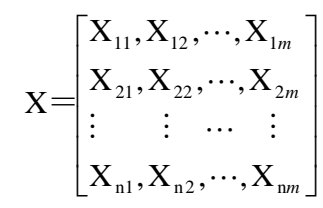

\subsubsection{The selection of the principal component of} the real estate economic benefits risk

(1) First, the original data is standardized.

$$
\mathrm{X}_{i \mathrm{k}}=\frac{\mathrm{X}_{i \mathrm{k}}-\bar{X}_{k}}{S_{k}} \quad i=1,2, \cdots, n ; k=i=1,2, \cdots, m ;
$$

(2) Calculate the correlation coefficient matrix. 


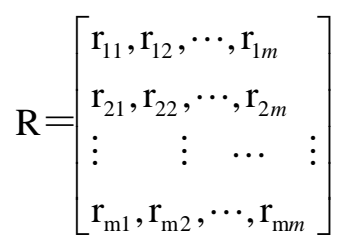

Where $r_{i j}=\sum_{i=1}^{n}\left(\frac{\mathrm{X}_{\mathrm{k} i}-\mathrm{X}_{\mathrm{kj}}}{n}\right) ; j=1,2, \cdots, m$;

(3)Non-negative eigenvalues of Jacobi matrix R: $\lambda_{1} \geq \lambda_{2} \geq \cdots \lambda_{m} \geq 0 \quad, \quad$ obtained the corresponding eigenvectors. According to eigenvectors, establish the mathematical model of the principal component analysis.

(4)Select the principal component

The principal component is selected according to the size of its contribution rate. Principal component variable cumulative contribution rate should be large than 70 percent.

\subsubsection{Logistic regression models of real estate economic benefits risk}

In the study of the risk of real estate economic benefits, variables can be divided into two types: risk or no risk variables.

Assuming a theoretical continuous response variable represents $y_{i}$ : the likelihood of the risk of real estate economic benefits, the value range is negative infinity to positive infinity. When the value of the variable across a critical point $\mathrm{c}(\mathrm{eg} \mathrm{c}=\mathrm{o})$, will lead to events. So:

$$
\begin{array}{rlrl}
\text { When } & y_{i}>0, & y_{i} & =1, \\
\text { Others } & y_{i} & =0 .
\end{array}
$$

If the distribution of the risk of real estate economic benefits is Logistic, then

$$
\begin{aligned}
& \mathbf{F}\left(\alpha+\beta x_{i}\right)=\frac{1}{1+e^{-\left(\alpha+\beta_{1} x_{1}+\beta_{2} x_{2}+\cdots+\beta_{i} x_{i}\right)}} \\
& \text { so } P\left(y_{i}=1 \mid x_{i}\right)=\frac{1}{1+e^{-\left(\alpha+\beta_{1} x_{1}+\beta_{2} x_{2}+\cdots+\beta_{i} x_{i}\right)}} \\
& =\frac{e^{\alpha+\beta_{1} x_{1}+\beta_{2} x_{2}+\cdots+\beta_{i} x_{i}}}{1+e^{\alpha+\beta_{1} x_{1}+\beta_{2} x_{2}+\cdots+\beta_{i} x_{i}}}, \text { it is Logistic model. }
\end{aligned}
$$

4 EMPIRICAL ANALYSIS OF THE RISK ASSESSMENT OF THE ECONOMIC EFFICIENCY OF REAL ESTATE LISTED COMPANIES

\subsection{The correlation test of economic benefits risk of real estate listed companies}

Select a sample of 2012 (ST Enterprise 4, non-ST companies 95) and eight economic benefits index, use SAS8.0 software to analyze principal component of these index. First, analyze the characteristic of the correlation variables.

Table1 Variable correlation test

Kaiser's Measure of Sampling Adequacy: Overall MSA $=0.67307059$

\begin{tabular}{|l|cccc|}
\hline variable & $\mathrm{X}_{1}$ & $\mathrm{X}_{2}$ & $\mathrm{X}_{3}$ & $\mathrm{X}_{4}$ \\
\hline MSA & 0.4767 & 0.4590 & 0.4148 & 0.7855 \\
\hline variable & $\mathrm{X}_{5}$ & $\mathrm{X}_{6}$ & $\mathrm{X}_{7}$ & $\mathrm{X}_{8}$ \\
\hline MSA & 0.7317 & 0.7893 & 0.6815 & 0.8412 \\
\hline
\end{tabular}

According to the test results of Table 1, that the variable correlation is generally strong, and the MSA $=0.67>0.5$, the effect of the principal component analysis is good.

\subsection{The principal component of the risk of economic efficiency of real estate listed companies}

As can be drawn from Table 2, the characteristic values of three eigenvectors cumulative contribution rate get 75.18 percent of the total variance, and the variance of values are greater than 1 , so the number of principal components can be obtained, it is three.

Table2 Economic benefits the risk principal component selected

\begin{tabular}{|c|c|c|c|c|}
\hline & Eigenvalue & Difference & Proportion & Cumulative \\
\hline 1 & 3.1449 & 1.3067 & 0.3931 & 0.3931 \\
\hline 2 & 1.8382 & 0.8070 & 0.2298 & 0.6229 \\
\hline 3 & 1.0311 & 0.2142 & 0.1289 & 0.7518 \\
\hline 4 & 0.816 & 0.3214 & 0.1021 & 0.8539 \\
\hline 5 & 0.4954 & 0.2051 & 0.0619 & 0.9159 \\
\hline 6 & 0.2903 & 0.0045 & 0.0363 & 0.9522 \\
\hline 7 & 0.2857 & 0.188 & 0.0357 & 0.9879 \\
\hline 8 & 0.0970 & 0.0121 & 1.0000 & \\
\hline
\end{tabular}

\subsection{Economic efficiency risk model of real estate listed companies}

According to Table 3, construct a model of the main component.

$$
\begin{aligned}
\text { Prin } 1= & -0.0713 \mathrm{X}_{1}-0.1564 \mathrm{X}_{2}+0.1032 \mathrm{X}_{3}-0.048 \mathrm{X}_{4} \\
& +0.5062 \mathrm{X}_{5}+0.4983 \mathrm{X}_{6}+0.5221 \mathrm{X}_{7}+0.4248 \mathrm{X}_{8} \\
\text { Prin2 }= & 0.6439 \mathrm{X}_{1}+0.4477 \mathrm{X}_{2}+0.4273 \mathrm{X}_{3}+0.4072 \mathrm{X}_{4} \\
& +0.0708 \mathrm{X}_{5}+0.0885 \mathrm{X}_{6}+0.1096 \mathrm{X}_{7}-0.1081 \mathrm{X}_{8} \\
\text { Prin3 }= & -0.0416 \mathrm{X}_{1}+0.5982 \mathrm{X}_{2}-0.7254 \mathrm{X}_{3}+0.2065 \mathrm{X}_{4} \\
& +0.0359 \mathrm{X}_{5}+0.0883 \mathrm{X}_{6}+0.0137 \mathrm{X}_{7}+0.2496 \mathrm{X}_{8}
\end{aligned}
$$


Table3 Principal component eigenvectors

\begin{tabular}{|c|c|c|c|}
\hline & Prin1 & Prin2 & Prin3 \\
\hline $\mathrm{X}_{1}$ & -0.071305 & 0.643912 & -0.041589 \\
\hline $\mathrm{X}_{2}$ & -0.156426 & 0.447674 & 0.598205 \\
\hline $\mathrm{X}_{3}$ & 0.103182 & 0.427343 & -0.725405 \\
\hline $\mathrm{X}_{4}$ & -0.047656 & 0.407195 & 0.206524 \\
\hline $\mathrm{X}_{5}$ & 0.506167 & 0.070761 & 0.035933 \\
\hline $\mathrm{X}_{6}$ & 0.498304 & 0.088536 & 0.088225 \\
\hline $\mathrm{X}_{7}$ & 0.522098 & 0.109598 & 0.013660 \\
\hline $\mathrm{X}_{8}$ & 0.424770 & -0.108064 & 0.249589 \\
\hline
\end{tabular}

Let's to get $\mathrm{X} 1, \mathrm{X} 2, \ldots, \mathrm{X} 8$ into matrix, you can calculate the principal component values of the three samples, using logistic regression analysis, get the real estate economic benefits risk model.

$$
\mathrm{F}(x)=\frac{e^{-5.2904-2.3402 Z_{1}-2.3062 Z_{2}-0.537 Z_{3}}}{1+e^{-5.2904-2.3402 Z_{1}-2.3062 Z_{2}-0.537 Z_{3}}}
$$

Table4 Real estate economic benefits risk model coefficient estimates

\begin{tabular}{|l|l|l|l|l|}
\hline Parameter & Estimate & Error & Chi-Square & $\mathrm{Pr}>$ ChiSq \\
\hline Intercept & -5.2904 & 1.8110 & 8.5336 & 0.0035 \\
\hline$z_{1}$ & -2.3402 & 4.0658 & 0.3313 & 0.5649 \\
\hline$z_{2}$ & -2.3062 & 1.4893 & 2.3980 & 0.1215 \\
\hline$z_{3}$ & -0.5371 & 0.6284 & 0.7305 & 0.3927 \\
\hline
\end{tabular}

The models were tested, the results are shown in table 5, the deviance statistics and Pearson statistics are 0.2650 and 0.4209 , its value is less than 1 , indicating that the model is better. Hypothesis testing of model coefficients, as shown in table 6, the Wald statistic is 4.6808> 3.84, the model fits better.

Table5 Real estate economic benefits of risk models fit test

\begin{tabular}{|l|lccc|}
\hline Criterion & DF & Value & Value/DF & Pr $>$ ChiSq \\
\hline Deviance & 95 & 25.1752 & 0.2650 & 1.0000 \\
\hline Pearson & 95 & 39.9853 & 0.4209 & 1.0000 \\
\hline Number of unique profiles: 99 \\
\hline
\end{tabular}

Table6 Real estate economic benefits risk model coefficients fit test

\begin{tabular}{|l|lcc|}
\hline Test & Chi-Square & DF & Pr $>$ ChiSq \\
\hline Likelihood Ratio & 8.3316 & 3 & 0.0396 \\
\hline Score & 4.9140 & 3 & 0.1782 \\
\hline Wald & 4.6808 & 3 & 0.1967 \\
\hline
\end{tabular}

Based on degree of confidence 5 percent, test the economic benefits risk of the 2012. Among 99 listed real estate, 4 ST 2 are wrong, two right, the correct rate is 50.00 percent, 18 of 95 non-ST companies are wrongly convicted, and 77 are correct, the correct rate of 81.05 percent. Overall, among 99, 20 are wrongly convictions, and 79 are correct, the correct rate of 79.8 percent, indicating that the model prediction accuracy rate is higher.

Table7 the Logistic model 2012 judgment result

\begin{tabular}{|c|c|c|c|c|c|c|}
\hline \multirow{2}{*}{ year } & \multirow{2}{*}{\multicolumn{2}{|c|}{$\begin{array}{l}\text { Predictive } \\
\text { value }\end{array}$}} & \multicolumn{2}{|c|}{ Original value } & \multirow{2}{*}{ Total } & \multirow{2}{*}{$\begin{array}{l}\text { Correct } \\
\text { rate }\end{array}$} \\
\hline & & & 1 & 0 & & \\
\hline \multirow{4}{*}{2012} & \multirow{2}{*}{ count } & 1 & 2 & 2 & 4 & \multirow{4}{*}{$79.8 \%$} \\
\hline & & 0 & 18 & 77 & 95 & \\
\hline & \multirow{2}{*}{ percentage } & 1 & $50 \%$ & $50 \%$ & $100 \%$ & \\
\hline & & 0 & $19.95 \%$ & $81.05 \%$ & $100 \%$ & \\
\hline
\end{tabular}

\section{CONCLUSION}

1. China's real estate market is seller's market; demand of commercial housing is larger. Overall efficiency of the real estate business is better; therefore, the risk of the economic benefits of the real estate business is not high.

2. Using Logistic method to assess of the economic benefits of the risk of real estate listed companies accuracy gets to 79.8 percent. Logistic method of economic benefits risk model of real estate listed companies is reliable.

3. Due to the limitations of the sample, the accuracy of the economic benefits risk of listed companies is only 50 percent. So sample should also be increased, it will improve the accuracy of the assessment.

\section{REFERENCES}

[1] Li Yi. Evaluation and application of real estate investment risk based on SVM, statistic and decision.2012(1:70-72

[2] WANG Guang-yue, CHENG Ji-guang, FU Zhi-qian. Multi objective decision analysis and application real estate investment risk, Mathematics In Practice and Theory. 2003(5):26-29

[3] YONGDONG SHI RIQING CHEN. Real estate price decision under conditions of uncertainty: a stochastic model and empirical analysis. China Economic Quarterly. 2009(1):211-230

[4] Logistic Regression Examples Using the SAS System.SAS Institute Inc. 1995

[5] Roncek, D.W. Using logit coefficients to obtain the effects of independent variables on changes in probabilities. Social Forces.1991(7):509-518

[6] ZHAO Liang; WANG Lian-guang. The research of Shenyang real estate market based on generalized regression neural network. Journal of Northeastern University (Natural Science). 2014(8): 1203-1205 